\title{
DIE WET VAN GOD - 'N TEOLOGIESE EN WYSGERIGE STUDIE
}

W.J. Ouweneel

Departement Wetenskapsleer

Potchefstroomse Universiteit vir $\mathrm{CHO}$

POTCHEFSTROOM

\begin{abstract}
The theological tcrm law of God is discussed in relution with its significance for other scholarly disciplines, in particular for philosophy. First, the idea of creational ordinances is viewed with respect to the underlying notion of law. Secondly, the idea of the law as being 'border' is discussed. According to this view cenain entities of reality are classified as being 'under' (i.e. within the law) and others as 'above' the law. Other points discussed are the creational meaning of the law-order. the relationsizip of law and cosmic time, and the description of law in modal tems used not as concepts but as ideas. The positivizing of law is viewed from what is considered to be the correct wiew-point, as well as from the biblicistic view-point. Finally, the cosmological meaning of law is discussed in coherence with the fall and with the redemption in Christ. In this context, the view is defended that the law, being, in its supratemporal fulness, Christ Himself, does not 'belong' to creation, as is oflen asserted.
\end{abstract}

\section{DIE KOSMIESE WETSORDE}

\subsection{Inleiding}

Die term wet van God speel 'n belangrike rol binne die dogmatiek, baie belangriker as wat in hierdie artikel aan die orde kan kom. Die betekenis van die wet strek egter ook verder as die teologie deurdat dit ook van groot belang is vir 'n Christelike beoefening van die ander vakwetenskappe en van die filosofie. Dit is daarom die doel van hierdie artikel om kortliks die wysgerige implikasies van die teologiese term wet van God te bespreek. Daarby word onder andere aandag gegee aan die begrip skeppingsordinansie, aan die idee van die wet as 'grens' tussen Wetgewer en skepsel, aan die vraag na die geskape-wees (al dan nie) van die wet(sorde) en die verhouding tussen wet en tyd. Die belang van 'n dergelike studie is onder andere geleë in die voortgaande diskussie met die skolastiek (wat nog steeds 'n belangrike invloed binne die reformatoriese teologie uitoefen), die biblisisme en die humanistiese invloede binne die modern(isties)e teologie. 
Van oudsher af het die ordelikheid en wetmatigheid wat die werklikheid kenmerk, baie denkende mense getref. Die geloof in 'n wêreldorde kom 'n mens dan ook in allerlei godsdienste teë. In soverre die Westerse denktradisie 'n goddelike wêreldorde erken, spreek dit byvoorbeeld van die lex aeterna (skolastiek) of die harmonia praestabilita (Leibniz), en dies meer. Ook het alle wysgerige stelseis implisiet of eksplisiet 'n bepaaide idee van 'n sekere wêreld- of wetsorde, of die wysgeer hom nou daarvan rekenskap gee of nie. Die bestaan van 'n wetsorde kan nie rasioneel bewys word nie, maar moet geglo word; elke poging tot bewys veronderstel immers reeds die logiese denkwette, en daarmee die wetsorde self. Dat die bestaan van 'n wetsorde geglo moet word, toon aan dat nie net alle godsdienste en alle wysgerige stelsels nie, maar ook alle wetenskaplike navorsing in 'n geloofsvooroordeel gegrond is wat nie logies-rasioneel verantwoord kan word nie. Hierdie premisse behels dat ' $n$ objektiewe wetsorde bestaan, en dat die hoofdoel van alle navorsing die ontsluiting van hierdie wetsorde is. ${ }^{1}$

\subsection{Die skeppingsordinansies in die Skrif}

Die Joods-Christelike tradisie verstaan die wetsorde op grond van die Skrif as skeppingsorde, dit wil sê as 'n orde wat deur die Skepper ingestel is en gehandhaaf word, en waarin afsonderlike skeppingsordinansies onderskei word. Hierdie insig berus op baie Skrifuitsprake, soos byvoorbeeld die volgende:

- Alle dinge is gegrond in God se soewereine Skeppers-wil (Op. 4:11).

- Die hemelliggame gehoorsaam God se verordeninge, insettinge, bepalinge, bevele (Job 38:33; Ps. 119:91; 148:6; Jes. 45:12; Jer. 31:35; 33:25).

- Ook die aardse natuur gehoorsaam sy stem, sy bevele (Ps. 104:6,7; 147:15,18).

- Met betrekking tot die vaste reëlmaat van dag en nag geld God se verbond (Jer. 33:20,25; vgl. Ps. 89:3,4,6,38).

Hierdie verordeninge mag nooit beskou word in deïstiese sin asof die skepping 'n reusagtige 'outomaat' is nie. Die Skrif lê groot klem op wat genoem word die werk van die onderhouding, waardeur alles wat in die werklikheid en in die geskiedenis plaasvind, herlei word tot God se direkte handeling. Die Skrif getuig dat God nie net in,

1 Kyk daaroor Hart (1984:25 e.v.; hy verwys na Hempel, Popper, Radnitzky, Stchbing en Toulmin) en Stafleu (1987:240; hy verwys na Bunge en Popper) 
deur en vir Christus alles geskep het nie, maar ook dat alles deur Christus in stand bly (Kol. 1:16,17); God het deur sy Seun die wêreld geskep en hou ook alle dinge deur sy magswoord in stand (Heb. 1:2,3); Hy gee "aan almal lewe en asem en alles", en "deur Hom lewe ons, beweeg ons en bestaan ons" (Hand. 17:25,28; vgl. Dan. 5:23). In alles wat in die natuur gebeur, is God se hand voortdurend aanwesig, is God voortdurend met sy woord teenwoordig. ${ }^{2}$ Soos Grundmann (1964:290) dit uitdruk:

In place of the neutral forces of nature [soos in dic Griekse en Hellenissiese denke] we have the power and might of the personal God, which do not operate in terms of immanent law but which rather carry out the will of (iod according to His direction.

Daarnaas maak die Skrif nog ontelbare afsonderlike uitsprake oor God se handeling in die natuur. God spreek in die donderstorm, Hy laat dit reën en sneeu, Hy stuur die storm en maak die ys, Hy gebied die dag en die nag en die hemelliggame, Hy voed en lei die dierewêreld en bestier die plantewêreld, Hy stuur die fonteine en spruite (Job 37-39; Ps. 29; 104). Dit alles is God se handeling in die natuur. en al hierdie handelinge van God is sy wonders (Job 37:14: Ps. 139:14). Die Skrif ken die skolastiese onderskeid tussen natuurlike en bo-natuurlike wonders glad nie. Dit gaan in álles om God se wonderbaarlike handeling, dit is alles volkome 'natuurlik' vir Hom, hoe wonderlik sy dade ook al vir' $n$ mens lyk.

Die Skriftuurlike uitsprake oor verordeninge, insettinge waarin die skeppingswerklikheid gegrond is, wys op die vaste reëlmaat wat aan die kosmos inherent is. Dit gaan hier om God se wet. Daar is vir hierdie uitsprake baie (indirekte) Skrifbewyse. So word die ordinansies wat God vir die natuur ingestel het, in Psalm 19 in een asem genoem met die wet soos God dit vir die mens se lewe ingestel het. Die woord wet in Psalm 19:8 dui eintlik die hele goddelike openbaring aan (vgl. Gutbrod, 1967:1046, waar ook nog Ps. 1:2 en 94:12 genoem word). In die twaalfde strofe van Psalm 119 (vs. 89-96) gaan dit eintlik om een 'wet', een 'woord' van God vir sowel die lewelose dinge as vir die mens. Op minder duidelike wyse is daar ook in Psalm 93 'n dergelike verband tussen die natuur enersyds en die heiligheid van God se huis andersyds, en in Psalm 147 tussen God se handeling met sy volk enersyds en sy handeling in die natuur andersyds. Blykbaar word hier nooit spanning tussen hierdie 'kosmiese' en

2 (jod se skeppingswoord is altyd aktueel (van Lat. actus, "daad, handeling"), dil wil sî (jod se (skcppende en onderhoudende) woorde en (skeppende en onderhoudende) dade vloci hier in mekaar in. Dit stem oorecn met dic feit dal dic Hebrecuse dabar sowel 'woord' as 'saak' (soms in dic betekenis 'daad') beteken. Ook dic Grickse logos kan soms 'saak' met dic betekenis van 'daad' beteken (Hand. 8:21: "wcrk"). Dic onderskeid tussen woord- en werkopenbaring (Ouweneel, 1991) stuit dus op dic feit dat die skerp onderskeid tussen woord en werk nic gehandhaaf kan word nie. 
'soteriologiese' aspekte gevoel nie (Berkouwer, 1951:102; Kraus, aangehaal in Schmidt, 1977:129). Daar is basies net een wet vir die natuur en vir die menselewe. Die wet is baie meer as net die wet van Moses; dit gaan om die totale orde wat God vir al sy skepsels ingestel het (vgl. Greidanus, 1991:25-28).

Dat die natuurverskynsels aan God se wet onderworpe is, is 'n taamlik resente insig. Die idee van 'natuurwette' het vir die eerste keer opgekom by die Christen-grondleggers van die moderne natuurwetenskap: Kepler, Galileo, Descartes en Newton (Stafleu, 1987:238-240, 256). In die Middeleeue het die begrip wet soos ons dit ken, nog nouliks bestaan. Eers ná die Reformasie het mense begin om byvoorbeeld die staatswette te sien as gegrond in fundamentele idees soos geregtigheid, vryheid of menseregte, wat weer gegrond is in die skeppingsorde. Die Hervormers het klem gelê op God se trou aan sy verbond jeens sy volk in verband met die wette wat $\mathrm{Hy}$ aan die skepping opgelê het, iets wat ook die natuurwette insluit. Calvyn het gestel dat nie net die natuurwette nie, maar alle wette, selfs (contra Descartes) die logiese wette, alleen van krag is solank hulle in stand gehou word deur die Skepper, vanweë sy verbond waarin Jesus Christus die Middelaar is.

Hierdie verbinding tussen wet en verbond is baie belangrik. Jeremia $33: 20,25$ is al genoem, waar sprake is van God se 'verbond met die dag en die nag' en sy 'voorskrifte vir die hemel en die aarde'. In Psalm 78:10 wys die poëtiese parallelisme op 'n duidelike relasie tussen 'verbond' en 'wet' (vgl. Deut. 31:9). In Psalm 89:3 (1933vertaling) is sprake van God se (verbonds)trou ten opsigte van die hemele (hemelliggame), en parallel daarmee word God se verbond met Dawid in vers 4 genoem. In groot dele van hierdie psalm word 'n parallel getrek tussen God se trou ten opsigte van die hemelliggame en sy verbondstrou aan die huis van Dawid (vs. 6,9,29,30,37,38). Hierdie nadruk op God se verbondstrou het die grondleggers van die moderne natuurwetenskap geïnspireer om op soek te gaan na hierdie natuurwette, en wel nie in die eerste plek deur rasionele denke nie, maar deur empiriese navorsing, waarin rasionele denke saamwerk met waarneming en eksperiment. In die nominalisme is elke veralgemening ongegrond, behalwe as 'n praktiese middel tot denkekonomiese ordening van die menslike ervaring. Kepler, Pascal, Boyle en Newton het egter die grond vir 'n dergelike veralgemening gesoek in God se belofte om die skepping te onderhou. 


\section{DIE WET AS 'GRENS’}

\subsection{Die idee van die grens}

In die Christelike belydenis omtrent die wetsorde moet dit by voorbaat absoluut vasstaan dat God die Oorsprong en Onderhouer van die kosmiese wetsorde is en tegelyk bo hierdie wetsorde verhewe is. Calvyn het al tereg gesê: Deus legibus solutus est, sed non exlex (God is bo die wette verhewe, maar is nie 'wetteloos' in die sin van willekeurig nie). ${ }^{3}$ Die mens staan onder die wet as die universele grens (wat nie oorskry kan word nie) tussen die Skepper en die skepsel. Dit is net so wesenlik dat God nie aan die wet onderworpe is nie as dat al wat geskape is, dit wel is; die bestaan van die geskapene word beperk en bepaal deur die wet. Christus was wat sy menslike natuur betref onder die wet (vgl. Gal. 4:4), maar nie wat sy goddelike natuur betref nie (Dooyeweerd, 1984:99,108).

Hierdie 'grens' kan natuurlik nie ruimtelik wees nie, omdat die ruimtelike self tot die geskapene behoort en ' $n$ ruimtelike grens binne die kosmos dus slegs iets van iets anders binne die kosmos kan afbaken (Vollenhoven, 1933:24,25). Praat ons oor 'grens' in streng ruimtelike sin, dan het ons met 'n ruimtelike begrip te doen, deurdat hierdie begrip ruimtelike eienskappe insluit, dit wil sê gegewens wat binne die grense van die ruimtelike aspek funksioneer. Hierdie ruimtelike term kan egter ook gebruik word om ideematig te verwys na gegewens wat die grense van die ruimtelike aspek oorskny (vgl. hoe die woord grens reeds in hierdie sinne gebruik word!), soos wanneer ons praat oor die wet as 'grens'. Hierdie begrip is nie 'n streng ruimtelike begrip nie, maar 'n idee (ook wel grensbegrip genoem, waarin die woord 'grens' ook weer ideematig gebruik word) (vgl. Strauss, 1988a:147-150).

\subsection{Die vervaging van die grens}

Daar het altyd die groot versoeking bestaan om die wet of te herlei (of te reken) tot die skepping, of te identifiseer met die Skepper, en dus die wet te vergoddelik. Dit is baie belangrik om hier die regte ewewig te bewaar. Die wet is enersyds die woord wat uitgaan van God, sonder om met God sonder meer geïdentifiseer te word, en andersyds

3 Vollenhoven (1933, bylae: nool 480) gec die volgende verwysings: De aeterna pracdestinatione 1552 (Comus reformatonum 36, kolom 361) en Commentarius in Mosis libros 5.1563 (Corpus ref. 52, kolom 49 en 131); kyk ook sy notc $481 \mathrm{cn} 482$, en noot 2: dic solutus beteken nic "dat God Zich in Zijne verhouding tol het schepsel nict trouw aan Zijn wetten zou houden" nie. "maar dat God - anders dan Z'n schepsclen - Zelf niet onder de wet staat". 
is die wet die woord wat geld vir die skepping, sonder om aan die skepping toegereken te word. Myns insiens het Vollenhoven (1963:2,8) dit goed weergegee in die trits God - wet - kosmos, wat ook voorkom by sy leerlinge, soos Taljaard, Wolters en Hart. Dit is wel begryplik dat baie teoloë en wysgere met die besonder gekompliseerde relasie tussen God, wet en kosmos gesukkel het. ${ }^{4}$ Slegs enkele verkeerde opvattinge word hier genoem:

* God onder die wet. Dit is die siening wat ook God 'onder' die wetsgrens plaas asof Hy aan sy eie wetsorde onderworpe sou moet wees. So byvoorbeeld word geredeneer dat ook God noodwendig aan die denkwette en morele wette onderworpe is: Hy gebied die goeie omdat die goeie goed is en aan hierdie ewige feit dat die goeie gewoon goed is, kan selfs God niks verander nie ('n siening van byvoorbeeld Grotius). En Husserl het gesê dat God aan die wiskundige waarhede niks kan verander nie, omdat hulle 'n absolute bestaan het.

* God 'wetteloos'. Ander denkers het die omgekeerde fout begaan en het die feit dat God bo die wet verhewe is, geïnterpreteer as tirannieke willekeur (Ockham) - asof selfs 'willekeurige handeling' nie al 'n norm veronderstel waaraan hierdie handeling onderworpe is en waaraan die willekeurigheid of onwillekeurigheid gemeet kan word nie. Ten diepste kan niks sinvols oor die genormeerdheid al dan nie van God se handelinge gesê word nie, aangesien alle denke daaroor self tot hierdie sy van die wetsgrens beperk bly.

* Die wetsgrens uitgewis. Dit gebeur byvoorbeeld in die panteïsme, wat God met die kosmos identifiseer (byvoorbeeld by Spinoza).

* Die wet as behorende tot die subjekte. Verwante foutiewe opvattings impliseer dat die wetsy en die subjeksy verwar word. Die wet word dan aan die subjeksy geplaas, veral in die menslike rede (o.a. deur die nominaliste) of in die geskiedenis in sy totaliteit of in die afsonderlike verskynsels. Dit is egter onjuis dat slegs die subjeksy objektiewe bestaan het.

* Die wet verabsoluteer. In die Skrif is die wet nie absoluut nie, maar relasioneel, dit wil sê dit verteenwoordig 'n betrekking tussen God (die Wetgewer) en die skepsel (dit wat onder die wet gestel is). Die wet mag nooit verabsoluteer ('vergoddelik')

4 Kyk Dengerink (1986:138-142,175,178, cintlik die hele hoofstuk 4) en Kalsbeck (1970:66-71) vgl. Hcyns (1978:118): "Enige wysgerige of ander standpunt wat die kosmicse wetsorde loen, vcrabsoluteer, subjcktiveer of relativcer, sal op Bybclse grondc afgewys moet word." 
word nie, soos die begripsrealisme doen (Van Riessen, 1980:144). In byvoorbeeld Plato se ideëleer word die wet losgemaak van God en verselfstandig tot 'n metafisiese ryk van norme en waardes wat 'bo' die mens verhewe is en waartoe die Godheid self as hoogste Idee gereken word.

\section{ANDER KENMERKE VAN DIE WETSORDE}

\subsection{Die sin van die wetsorde}

Die sin van die wetsorde wat God ingestel het. is God se eis teenoor al sy skepsels wat daarin uitgedruk word. Hierdie sin is geleë in God se verheerliking, om Hom te dien, en - wat die mens betref - Hom lief te hê bo alles. Hierdie liefdesgebod impliseer binne die universele wetsorde tegelyk 'n belangrike verskil met die natuurwette. Die liefdesgebod geld net vir die mens, naturwette geld (geheel of gedeeltelik) vir alle skepsels. Natuurwette sê hoedat iets 'is' ('koper sit uit by verhitting') en norme of normatiewe wette sê hoedat iets 'behoort' te wees ('jy moet jou naaste lief hê soos jouself). Natuurwette kan nie oortree word nie ('n mens het byvoorbeeld nie die intrinsieke moontlikheid om sy val te onderbreek nie), terwyl die mens as vrye en verantwoordelike skepsel verplig is om die norme te gehoorsaam, maar die intrinsieke moontlikheid het om ongehoorsaam te wees. Natuurwette is dwingende wette, norme is dringende wette.

Dengerink betoog dat binne die skepping die mens die enigste skepsel is wat in die volle sin van die woord op God se skeppingswoord antwoord kan gee. Deurdat sy wetsrelasie tot God nie natuurwetmatig is nie, maar normatief, dra hy ten opsigte van die skeppingswoord verantwoordelikheid, wat hy nooit kan aflê nie, solang hy onder die skeppingswoord staan (dit is vir ewig). Die mens is daarom volgens Dengerink $(1986: 124,175,181,211,251,335,338,339,353)$ die enigste skepsel wat transendentaal bepaal is as antwoordstruktuur. Hierdie siening verbind hy met die menslike aktstruktuur $(338,339)$. Die mens se antwoord is 'n reaksie op die uitnodiging van God se skeppingswoord in sy voortdurende aktualiteit, en dit self word tegelyk deur hierdie skeppingswoord moontlik gemaak en gedra.

Teenoor die drang wat die skeppingswoord op die mens uitoefen, 'n woord wat 'n appèl rig tot sy verantwoordelikheid, stel God van sy kant sy verbondstrou (vgl. \$ 1.2 en 2.1,2). God bind nie net die skepping (en daarmee die mens) aan sy wet nie, maar God verbind Hom tewens aan sy skepping (en daarmee aan die mens) in sy wet, sonder dat God aan sy wet gebonde is. Daarom is die wet die uitdrukking van sy trou jeens die 
Die wet van God - 'n teologiese en wysgerige studie

skepping en word die wet, soos gestel, selfs 'n verbond genoem. Vanweë hierdie onverbreeklike verbond kan die mens vas vertrou op die wetmatigheid van die werklikheid. Dit is absoluut noodsaaklik om op hierdie aarde te kan lewe. As 'n mens nie (bewustelik of onbewustelik) kon vertrou op die natuurwette (op die wet van die swaartekrag of van die inersie, die rekenwette, die fisiologiese wette vir die liggaam, ens.), op die denk- en kommunikasiewette nie (waardeur menslike verkeer moontlik is), ensovoorts, dan sou die bestaan in hierdie wêreld volstrek ondenkbaar wees. Dit is nie slegs belangrik om te glo in 'n God wat wonders doen en soms in die werklikheid totaal anders handel as wat 'n mens op grond van sy kennis van die wetsorde as moontlik beskou. Dit is ewe belangrik om te glo in 'n God wat sy trou betoon ó6k in die vastheid, die onverbreeklike reëlmaat van die kosmiese wetsorde.

\section{$3.2 \quad$ Wet en tyd}

'n Ander belangrike tema is die verhouding tussen wet en tyd, waar Dooyeweerd baanbrekerswerk gedoen het. Hy het sy idees oor die tyd met behulp van die prismametafoor ontwikkel: die idee van die tydelike sin-breking van die modale orde binne die empiriese werklikheid én die bo-tydelike konsentrasie van hierdie modale orde in die hart, en uiteindelik in die 'wortel' van die kosmos (die eerste respektiewelik die laaste Adam). Enersyds is die hart die bo-tydelike (transendente) volheid en eenheid van alle modale funksies, andersyds vorm die funksies die tydelike sin-breking van die hart.

In watter verhouding staan die wet tot die hart en die funksies? Die ewige, ongeskape God het die bo-tydelike, geskape hart van die mens aan sy sentraal-religieuse liefdeswet onderwerp. Dit is die een wet, in sy transendente, integrale sin-volheid en -totaliteit, wat binne die tydelike werklikheid in baie verskillende ordinansies uiteenval. Soos die bo-tydelike hart hom uitdruk in die tydelike funksies, so werk die een botydelike, sentrale liefdeswet via die hart deur in die tydelike, geskape wetskringe in 'n groot verskeidenheid van tydelike wette, norme, ordinansies. In sy bo-tydelike, sentraal-religieuse hart is die mens dus onderworpe aan die bo-tydelike, sentraalreligieuse liefdeswet; in sy tydelike funksies is die mens onderworpe aan die diverse tydelike wette van God se skeppingsorde. Om die genoemde metafoor toe te pas: die tydelike wette vorm die divergerende 'straalbreking' van die onverganklike, ewige, sentraal-religieuse liefdeswet; die liefdeswet is die bo-tydelike konvergensie- en integrasiepunt ('brandpunt') van alle tydelike wetskringe, van alle modale en entiteitswette wat die Skepper vir die tydelike lewe ingestel het. 
Soos gesê, sien Dooyeweerd die eintlike konsentrasiepunt van die kosmos nie in die bo-tydelike menslike hart nie, maar in die laaste Adam, in Christus. Dit is begryplik, want hy soek 'n konsentrasiepunt wat uiteindelik die hele geskape werklikheid transendeer, terwyl die bo-tydelike hart van die mens tog net so 'n geskape werklikheid as alle tydelike dinge in die kosmos is. 'n Mens kan egter nie sê dat die wet - nóg die tydelike wette nóg die bo-tydelike wet - in dieselfde sin 'skepsel' is nie (vgl. \& 5.2). Dit is die wet vir die skepsel, maar dit is die wet van Christus (Gal. 6:2), die (skeppings)woord van Hom wat die Woord is (Joh. 1:1-3,14). Na sy menslike natuur het Christus deel geneem aan die skepping wat deur Homself tot stand gebring is (vgl. Kol. 1:15; Heb. 2:14) en Hom daarby onder die wet van God gestel (Gal. 4:4); maar na sy goddelike natuur is die laaste Adam tegelyk self die Skepper, wat self die wetswoord aan die skepping gegee het. gespreek het, ja, die ewige Logos is, wat alle dinge deur sy magswoord in stand hou (Heb. 1:3).

Dat die wet nie tot die skepping behoort nie, word uitgedruk in Vollenhoven (1963:2,8) se drieslag: God - wet - kosmos, en sy mening dat die wet nie in 'n ontologie verwerk kan word nie, en die kosmos wel. Die wet is volgens hom dit wat God vir die kosmos ingestel het, en is dus onderskeie van die kosmos as sodanig. Volgens Dooyeweerd egter het God die wet ingestel vir die subjekte en vorm wet en subjekte saam die kosmos. Die wet is by hom net 'n bepaalde sy van die kosmos self (die wetsy), onderskeie van die subjeksy (subjectus = onderworpe [aan die wet]). Volgens hierdie metafoor behoort die wet dus tot die skepping. Die wet kan in sy hoedanigheid as God se woord egter nooit tot die geskapene behoort nie; God se woord is nie 'n skepping van Hom nie, maar is self die skeppende woord (vgl. verder § 5.2).

\subsection{Die wet in ideematige sin}

In $\$ 2.1$ is in verband met die term grens gewys op die belangrike verskil tussen begrippe en idees. Ook oor die wet in sy bo-tydelike betekenis as God se skeppingswoord kan 'n mens net idee-matig spreek (vgl. Dengerink, 1986:129-132,223-240). Die 'werklikheid' van hierdie wet oorskry die grense van die geskape werklikheid, terwyl daaroor tog rasioneel en met behulp van modale terme gepraat kan word, wat dan egter nie begripsmatig gebruik word nie, maar ideematig:

- Aritmeties: Die wet van God in sentraal-religieuse sin is een, enkelvoudig en uniek, terwyl 'n veelheid en verskeidenheid tegelyk daarin opgesluit lê wat in die tydelike sin-breking tot ontplooiing kom. 
* Ruimtelik: In die bo-tydelikheid van die wet gaan dit duidelik om 'n ruimtelike idee, wat ook gesien word in die feit dat die wet die 'grens' is vir of 'n 'sy' is van die geskapene. Ruimtelik-ideematig word ook oor die wet gepraat as gewys word op sy 'uitgebreidheid', sy 'universele' geldigheid.

* 'Bewegingsmatig' (kinematies): In die 'transendensie' van die wet (wat die tydelike 'te bowe gaan'), en in die feit dat die wet sy eie 'beweging' van divergensie (van die bo-tydelike eenheid na die tydelike verskeidenheid) en konvergensie (in omgekeerde 'rigting') besit, gaan dit om 'n kinematiese idee.

* Fisies: Die wet van God is dinamies, het 'krag', is 'van krag' vir die hele werklikheid wat slegs 'kragtens' hierdie wet bestaan.

- Bioties: Die wet as die woord van die lewende God is die voortdurende lewensbron vir die skepping (vgl. Heb. 4:12; 1 Pet. 1:23).

* Perseptief: Die wet maak homself in alle dele en aspekte van die werklikheid konkreet merkbaar, sigbaar, hoorbaar, tasbaar. Die wetswoord is die woord van God se 'mond', wat deur alle skepsels 'gehoor' word; hulle ge-'hoor'-saam God se wetswoord.

* Sensitief: 5 Die wet is die openbaring van God se groot sorg en twegeneentheid jeens ons; hierdie wet beweeg ons gemoed (vgl. Ps. 19:8,9; 1933-vertaling).

* Logies: Die wet is logies samehangend, die uitdrukking van God se absolute Ratio. In hierdie term Ratio het ons weer met 'n ideematige gebruik van 'n term te doen; in die begripsmatige sin van hierdie term gaan dit om die ordelikheid en samehang ('rasionaliteit') van die kosmos en sy wyse van funksioneer, en ook om die rasionaliteit van die mens, waardeur die mens insig in die kosmos (én in die wet) kan verwerf. ${ }^{6}$

5 In Ouwencel (1986:55-126) word in plaas van die een psigiese aspek twee aspekte onderskei: dic perseptiewe en die sensitiewe aspek.

6 Vgl. Strauss (1983:53.55); Strauss \& Visagic (1984:54-58). N.B.: God sc 'rasionalitcit' cn die mens se rasionaliteit behoort nie lot dieselfde 'rasioncle orde' asol God aan dieselfde denkwette 'onderworpe' is nic, want dit sou betcken dat dic wet as grens tussen Wetgewer en skepsel uitgewis word (vgl. § 2.2), maar $\mathrm{Hy}$ hou hom wel trou aan dic denkwettc, soos uit sy Woord blyk (vgl. noot 3). 
* Kultuurhistories-formatief: Die wet is allesbeheersend en onweerstaanbaar, deurdat dit die uitdrukking van God se almag is. Die wet gee aan alles sy eie spesifieke vorm, soos God dit wil (Heb. 1:3b).

- Linguaal: Die wet is wetswóord, woord van God, spraak van God, openbaring van God, 'woord' wat gebiedend van Hom uitgaan sowel as 'woord' wat van Hom getuig: van sy ewige krag en goddelikheid (Rom. 1:20, 1933-vertaling) en van die werk van sy hande (Ps. 19:2-5). Die maan aan die hemel is die 'getuie' van God se bestendigheid (Ps. 89:38, 1933-vertaling).

* Sosiaal: Die wet is die waarborg dat alles met alles in die skepping saamhang, dat alles in die verband van 'n groot skeppingsgemeenskap gehandhaaf bly, deurdat alle dinge onder dieselfde wet gestel is, waardeur alle dinge nie net op die wet betrokke is nie, maar ook op mekaar.

* Ekonomies: Die wet is volmaak ewewigtig, doeltreffend, doelgerig: die woord van God "sal nie onverrigter sake na My toe terugkeer nie, maar dit sal doen wat Ek gedoen wil hê en tot stand bring waarvoor Ek dit gestuur het" (Jes. 55:11).

* Esteties: Die wet is volmaak in vrede en harmonie, soos God self, van wie die wet die uitdrukking is, die God van die vrede is, 'n vyand van alle wanorde (1 Kor. 15:32).

* Juridies: Die wet gee vir alles in die werklikheid 'n eie plek wat hom billik toekom; die wet se bepalings is regverdig (Ps. 119:62,75,106,138,142,144,160,164). Ook die term wet berus self reeds op ' $n$ ideematige gebruik van 'n juridiese begrip.

- Eties: Die wet is in die hoogste plek die liefdeswet van God, die uitdrukking van sy eie volmaakte liefde, waarmee Hy die wêreld in sy arms dra. Die wet toon die liefde van God vir sy skepping en wek op tot liefde vir Hom en die naaste, en selfs tot liefde vir die wet self (Ps. 119:47,48,97,113,119,127,140,159,163,167).

- Pisties ( = 'geloofsmatig'): Ons het gesien dat die wet die openbaring van God se verbondstrou aan sy skepping is. God se wet is geloofwaardig, en op grond daarvan weet 'n mens dat hy in 'n betroubare werklikheid lewe. God is trou; daarom is sy wetswoord ook trou (vgl. Ps. 19:8b). 


\section{POSITTVERING VAN WETTE}

\subsection{Korrekte positivering}

Die taak van 'n Christelike wysbegeerte sou omskryf kon word as die teoretiese analise van die Bybelse idee van die skeppingsorde of wetsorde. Die verskillende vakwetenskappe sou dan omskryf kon word as die pogings tot positivering van die afsonderlike wette (om 'n uitdrukking te gebruik wat aan die regwetenskap ontleen is). Deur die positivering van die wette word hulle afgelei, uitgewerk en vasgelê. Natuur- en geesteswetenskaplike navorsingsarbeid is 'n positiveringsproses van natuur- en geestesbeginsels, iets wat hulle 'begin' vind in God se skeppingswoord (vgl. Troost, 1969:21).

Daar is 'n fundamentele verskil tussen die wetsorde as sodanig en hierdie positivering. Die natuur se konstante natuurwetlike struktuurprinsipes en die menslike geestesbestaan se konstante normprinsipeswat God in die skeppingsorde veranker het, moet skerp onderskei word van die konkrete hipoteses, teorieë, 'natuurwette' en norme wat die resultaat is van die gebrekkige positiveringsarbeid deur die mens. Maar daarom hoef hulle nog nie noodwendig geskei word nie, asof hulle op geen manier by mekaar betrokke is nie; inteendeel, positivering is juis 'n goddelike opdrag aan die mens. Die mens se posisie in hierdie positiveringsproses is dan ook baie belangrik. Ten eerste is hy as beeld van God en hoof van die skepping die sentrale verwysingspunt waarop die opdrag wat in die goddelike skeppingsorde opgesluit lê ('onderwerp... heers...', wat ook inhou: verwerf kennis omtrent; Gen. 1:28, 1933-vertaling), gerig is. Ten tweede is dit dieselfde verwysingspunt waarvandaan die konkrete natuur- en geesteswetenskaplike teorievorming uitgaan (vgl. Troost, 1969:5). Hier blyk die fundamentele betrokkenheid tussen die skeppingsorde en die vakwetenskappe, en wel deurdat hulle 'saamkom' in die mens as verwysings- of betrekkingspunt.

Reeds in die Skrif is daar voorbeelde van hierdie positivering en van die eis tot positivering. Die een sentraal-religieuse, transendente liefdesgebod staan daar teenoor 'n verskeidenheid van modale en struktuurtipiese skeppingsbeginsels. Die algemene gebod: "Jy moet liefhê!" (vgl. 1 Joh. 4:19, waar 'n imperatief vertaal kan word, maar nie 'n objek genoem word nie) word deur Christus nader gedifferensieer as die liefdesgebod gerig op God en die liefdesgebod gerig op die naaste (Matt. 22:37-40), terwyl die Tien Woorde van die verbond 'n nadere positivering is van God se verbondswoord vir Israel. In elke kultuurhistoriese konteks moet vanuit hierdie 'wortel-wet' die gedifferensieerde verskeidenheid van verordeninge 'vertak' wat God vir die verskillende fasette van die menselewe ingestel het en wat deur die mens gepositiveer moet word (Strauss, 1990:10,11). 


\subsection{Biblisisme}

Strauss (1979:258,263,264; 1990:3-6,80-86; vgl. Smit, 1980:199) wys in hierdie verband op 'n belangrike eksegeties-teologiese kwessie, naamlik die gevaar van biblisisme. Die positivering van skeppingsbeginsels gebeur nie aan die hand van toepaslike Bybeltekste nie, asof dit vryelik nagelaat sou kon word waar sulke tekste nie beskikbaar is nie. Sowel die literalistiese gebruik van Bybeltekste as die veronderstelde onafhanklikheid van die Skrif waar geen direkte Skrifuitsprake gevind word nie, is verwerplik. Strauss (1990:4,5) noem as aanknopingspunt vir 'n Skrifgetroue benadering Jesaja 28:26-29, waar "God aan die mens kennis gee hoe om alles te doen soos dit hoort: swartkomyn en komyn word met 'n stok uitgeslaan; graan word gemaal vir brood; e.s.m. Dit behoort tot die uard, tot die God-geskape natuur van die dinge dat hulle sús of só gehanteer moet word. Danksy die ordelikheid van die dinge kom ons op die spoor van die orde wat God daarvóór gestel het! Só leer God ons hoe ons met sy skepsels moet omgaan - met inagneming van sy wil vir hul bestaan!"

Die punt van belang is nou dat God die riglyne hoe om te werk, nie in bepaalde Bybeltekste verskaf nie. Die boer ontvang die nodige insig van God deurdat God niks anders doen as om in sy verbondstrou sy wet vir die geskapene te handhaaf nie en deurdat die boer ag gee op die wetmatigheid van die geskapene. Op dieselfde wyse verwerf ' $n$ mens insig in die bou van atome of van lewende organismes, in die menslike psige, in denk- en taalprobleme, in tegniese, sosiale en ekonomiese vrae, in juridiese en etiese kwessies, ensovoorts, nie deur 'n beroep op Bybeltekste nie, maar deur in die wetenskaplike navorsing die wetmatigheid van die werklikheid te ondersoek en daardeur die wet van God vir die geskapene te probeer opspoor.

'n Regstreekse beroep op konkrete Bybeltekste is soms wel moontlik, maar meesal nie, waardeur die misverstand ontstaan dat die Bybel oor die betrokke gebied 'niks te sê het nie'. Die getals-, ruimtelike, fisiese, biotiese, psigiese, logiese, taalwette ensovoorts is almal in die skeppingsorde gegrond, maar kan nie eksplisiet in die Skrif teruggevind word nie; hulle moet in opdrag van God in moeisame navorsing opgespoor word (Dooyeweerd, 1963:56). Selfs wanneer 'n regstreekse beroep op Bybeltekste moontlik is, is dit soms misleidend, deurdat sulke tekste dikwels nie 'n bepaalde skeppingsbeginsel verskaf nie, maar 'n konkrete positivering van 'n skeppingsbeginsel in 'n bepaalde historiese konteks beskrywe. Dit is nie Bybels om sonder meer hierdie bepaalde positivering uit sy Bybelse konteks te lig en op die praktiese lewe toe te pas nie; dit is veeleer nodig om die onderliggende skeppingsbeginsel op te spoor. So is die monogame huwelik in die lig van Genesis 2:20-24; Matteus 19:3-8 en 1 Korintiërs 7 
ongetwyfeld 'n skeppingsbeginsel, maar die wyse waarop huwelike in die Bybel gerealiseer word (wyse van huweliksluiting, omgang van man en vrou, aantal vrouens, egskeidingsreëlings, ens.), word nader bepaal jeur die konkrete kultuurhistoriese konteks. Dit sou biblisisties wees om konkrete Bybelse positiverings van die huweliksbeginsel in ons eie konteks sonder meer te wou oorneem. ${ }^{7}$

Hier lê probleme wat nie net wysgerig nie, maar ook teologies van die grootste belang is. 'n Skeppings-'beginsel' is 'n konstante, nie-tydgebonde 'beginpunt' vir positivering in 'n bepaalde tyd en kultuurhistoriese konteks. Die skeppingsbeginsel hou altyd sy dringende, gelykblywende appel, ook al kan die positivering daarvan voortdurend verander. Hierdie baie belangrike onderskeiding bied die moontlikheid tot weerlegging van die konserwatisme, wat ten onregte vashou aan 'n bepaalde tydgehonde tradisie deur dit nie te onderskei van die onderliggende nie-tydgebonde skeppingsbeginsel nie (vgl. Hart, 1984:58-63).

\section{SONDEVAL EN VOLEINDING}

\section{$5.1 \quad$ Wetsorde en sondeval}

$\mathrm{Na}$ dit wat gesê is oor die skeppingsaard van die wetsorde, moet ook kortliks gewys word op die betekenis van die sondeval in hierdie verband. Ook aan hierdie kwessie is baie teologiese en wysgerige probleme verbonde, probleme wat veral met die verhouding tussen skepping en herskepping te doen het. Hierdie probleme kan hier nie uitvoerig bespreek word nie; slegs dié punte wat van belang is vir die betekenis van God se wet in die wetenskap kan hier aan die orde gestel word.

Deur die sondeval is die skeppingswerklikheid nie aan die wetsy nie, maar wel aan die subjeksy deur die sonde bederf. Deur die sondeval is nie die wetsorde verander nie want hoe sou die sonde God se altydblywende skeppingswoord kon beïnvloed? - maar net dit wat aan die wet onderworpe is, dit wil sê die funksionering daarvan onder die wet. Vir die regte verstaan van die kosmiese wetsorde is hierdie kwessie van groot belang. As die sonde naamlik ook die wetsorde sou versteur het, sou dit impliseer dat die sondeval die natuur van die geskapene vernietig het en daarmee sou sonde en

7 Die voorbeelde wat Strauss gee, is nie almal cwe toepaslik nie. So gee hy dic indruk $(1990: 81,84)$ asol die wet van Moses slegs juridiese gevolgsaansprecklikheid ken en nog nic rekening hou met die gesindheid van die dader nie. In dic lig van byvoorbecld Numeri 35:1525 is hierdie stelling myns insiens onhoudbaar. 
Satan 'n eiemagtige rol teenoor God speel, wat regstreeks God se soewereiniteit sou aantas (Dooyeweerd, 1963:58; vgl. ook 1984,I:63; II:32- 34,363).

Ook ná die sondeval mag die wette waaraan die werklikheid onderworpe blyk te wees, steeds skeppingsordinansies genoem word: dit is steeds die wette wat God oorspronklik by die skepping ingestel het. In die wyse waarin God ook ná die sondeval die kosmiese wetsorde in stand gehou het, kom sy genade teenoor die gevalle mensheid tot uiting. Hiervolgens laat Hy sy son opkom oor slegtes en goeies en laat Hy reën oor dié wat reg doen en oor dié wat verkeerd doen (Matt. 5:45). Deur hierdie genade is die skepping en die menslike samelewing ná die sondeval nie aan die mag van die kwaad prysgegee en het dit nie uitmekaar geval nie, maar het dit in stand gebly.

Nie die wetsorde self is vernietig nie, maar die gerigtheid van die menslike hart wat hom van God en sy wet afgekeer het. Die reformatoriese denke ken daarom die belangrike onderskeid tussen struktuur en rigting. Die sondeval het nie die struk. tuur(wette) aangetas nie, maar wel die rigting (gerigtheid) van die geskapene. ${ }^{8}$ Teenoor die gerigtheid op God staan die afgodiese gerigtheid, waardeur aan die subjeksy afgodiese uitsprake, handelinge en selfs afgod-gerigte samelewingsverbande ontstaan. God-gerigte en afgod-gerigte mense staan onder dieselfde wetsorde van God, maar hulle lewe vanuit verskillende rigtingkeuses van hulle harte. God-gerigte en afgod-gerigte mense praat, handel, vorm samelewingsverbande en by albei word hierdie norme en beginsels van God se wetswil veronderstel. Die God-gerigte mens kies egter die gehoorsaamheid aan hierdie norme as lewensbeginsel ('beginsel', want die praktiese verwerkliking is ook by hom nog dikwels sondig), terwyl die afgod-gerigte mens parasiteer op God se wet in óngehoorsaamheid. Ook die sonde veronderstel steeds die wet van God deurdat ongehoorsaamheid verwys na norme wat nie gehoorsaam word nie. Ook in norm-ongehoorsame gedrag bly die appèl van die norme herkenbaar.

Die norme wat aan die geesteslewe gestel is, is teonoom, dit wil sê hulle is nie deur die menslike rede geponeer (uitgevind, ontwerp) nie, maar deur God ingestel. Omdat God as Wetgewer een is, is ook die wet ten diepste (in sentraal-religieuse, bo-tydelike sin) een ( $\$ 4.2$ ), hoeveel afsonderlike (tydelike, gedifferensieerde) 'wetskringe' 'n mens

8 Heyns (1978:109) praat hicr van dic essensielc of substansiele sin van dic skepping (= struktuur) en sy historiese sin (= rigling); in die eerste sin van sy argumentasic noem hy dic skepping "normaal", in die lweede "abnormaal aangesien dil met die sonde deurdring is". Dic tcrm "substansieel" is myns insiens skolaslies te veel belas om nog bruikbaar te wees (kyk Ouweneel, 1986:294-312; vgl. Smit, 1980:184); dit is beter dat Heyns (1978:110) dic "substansiele" met dic wet verbind. 
ook al binne die wetsorde kan onderskei. Die sentraal-religieuse, bo-tydelike sin van die wet - waarin alle tydelike wetskringe konvergeer - is saamgevat in die groot liefdesgebod van Christus (Matt. 22:36-40; Joh. 13:34; 15:12,17; vgl. Rom. 13:10; Gal. 5:13,14; 6:2; Jak. 2:8; 1 Joh. 2:7-11; 3:11,23; 2 Joh. 5).

\subsection{Wetsorde en Christus}

Die hoogste dinge wat oor die wet opgemerk kan word, selfs met die oog op sy betekenis binne die filosofie en die vakwetenskappe, staan in verband met Christus. Die skepping is die 'beliggaming' van God se Woord; hierdie ewige Woord van God kry binne die tyd gestalte in die skepping van God in Christus, wat in persoon self die Woord van God én die Wortel van die skepping is. Hier kom ons by die geloofsdiepte wat in die Bybelse tema van die Wet opgesluit lê; 'n geloofsdimensie wat in 'n wysgerige diskussie as sodanig verder nooit aan die orde kom nie en volgens die aard van die wysgerige denke ook nooit kán kom nie. Wysbegeerte is 'slegs' 'n teorie omtrent die strukture van die geskape werklikheid; daarin speel ook die tema van die wet in soverre dit logies objektiveerbaar is 'n belangrike rol. Vir die (bo-teoretiese) geloof beteken hierdie tema egter oneindig mér; 'n geloofsrykdom wat origens tog weer deur die teologie ontsluit moet word. Die gelowige lê konfessioneel verantwoording af van sy geloof, maar dit is die teologie wat dit wát die gelowige glo en bely moet ondersoek na sy teoreties-analitiese aspek.

So raak ons hier teologies-wysgerig inderdaad aan 'n duidelike spanningsveld, soos in $\S 3.2$ reeds betoog is in die meningsverskil tussen Dooyeweerd en Vollenhoven oor die verhouding tussen wet en kosmos. Hierdie spanning is byvoorbeeld voelbaar by Heyns, wat enersyds sê: "Aan die skepping ... het God sy wetsorde gegee", wat impliseer dat skepping en wetsorde onderskei moet word, en direk daarna (enigsins teenstrydig) sê: "Tot die skepping behoort dus ook die wet" (Heyns, 1978:110). Die eerste uitspraak lyk wel korrek, maar die tweede lyk nie uit die Skrif bewysbaar nie, inteendeel. Is die wet skepsel? Is die wet nie God se eie woord nie? Die wet mag nooit vergoddelik word deur dit te verselfstandig ten opsigte van die Skepper nie $(\$ 2.2)$. Tog is die wet wel goddelik in dieselfde sin as wat God se woord, se dade, se krag goddelik is (vgl. 2 Pet. 1:3), dit is as behorende tot en uitgaande van Hom. Daarom lyk dit vir my onhoudbaar om te sê dat die wet geskape is of tot die skepping behoort.9 Dit word in die Skrif

9 Strauss (1988b:630-632) onderskei tussen Christus, wat dic Skepper en dic Woord is, en dic wetswoord vir die skepping, wat volgens hom to dic skepping behoort, terwyl hierdic wetswoord myns insiens in sy bo-tydelike sin-volheid identies met Christus as dic Woord is, en daarom (sélfs in die tydelike sin-breking) van dic skcpping onderskci moct word, omdat anders ' $n$ dualistiese skeiding tussen die wetswoord in sy bo-tydelike sin-volheid en dic 
duideliker as ons sien hoe die wet met Christus verbind word. God is in Christus die Wetgewer van die geskape werklikheid. Tog is Christus nie slegs as God die Seun die Wetgewer nie; Hy is as God-Mens die sin van die Wet op 'n dieper geloofsvlak, naamlik op dié vlak in die Skrif waar daar 'n intrinsieke samehang opgemerk kan word tussen die Torah van die Ou Testament én die Logos van die Nuwe Testament. dit is Christus, die Krag van God en die Wysheid van God (1 Kor. 1:24).

Die skepping bestaan volgens Johannes 1:3 deur die Logos, wat nie verstaan moct word as die intellektuele Ratio van die antieke denke nie (wat altyd na die menslike ratio verwys, wat op sy beurt weerspieël word in die kosmiese logos). Die skepping bestaan deur die Logos as uitdrukking van God se wese. Die Logos is die Rede, nie in die sin van Ratio nie, maar van Spraak (soos in die woord redenaar). God se wet het woord-karakter; sy wet is spreek, sy Torah (leer, onderwysing) is Logos (woord). God spreek om te skep (vgl. Gen. 1 [10x "God het gesê"]; Ps. 33:6.9; Jes. 48:13; Rom. 4:17), te onderhou (Ps. 119:89; 148:8), te verlos (vgl. 2 Kor. 4:6) en stel daarmee sy wet vir die skepping. Toral en Logos is een (vgl. uitvoerig Schmidt, 1977:123-125). Die tien 'woorde' (debarim; Eks. 34:28; Deut. 4:10,13,36; 5:5,22; 9:10; 10:2.4) is die tien gebooie (vgl. ook 'woord' vir 'gebod' in Eks. 24:3,4; Jos.4:26; 1 Kron. 15:15; Ps. 50:17 e.a.). So is daar ook 'n duidelike parallel tussen dabar en torah in Jesaja $1: 10$ en $2: 3$ (vgl. 42:4; 51:4,7), waarby torah die ruim betekenis van die openbaring van God se wil het.

Christus is die ewige Logos, want in Hom het God Homself volkome uitgedruk, geopenbaar; Christus is die uitdrukking van God in woord en werk. Vanweë die korrelasie van woord en wet is Christus egter in dieselfde sin die ewige Torah, want die Woord van God is altyd gebod van God; vgl. Johannes 14:21 ("my gebooie") met vs. 23,24 ("my woord", logos), en 12:49,50 (die gebod van Christus is die ewige lewe) met 1 Joh. 1:1,2; $5: 20$ (Christus Self is die ewige lewe). Ons het gesien dat die wet in sy botydelike volheid een is, maar dat dit in die tydelike 'sin-breking' in baie verskillende ordinansies uiteenval ( $\$ 4.2$ ). So divergeer die een, ewige Logos in die konkrete sinbreking binne die tydelike werklikheid ook in baie afsonderlike tydelike Logoi (uitsprake van God; vgl. byvoorbeeld logos en logoi in Joh. 14:23,24), en so word die ewige Torah gemanifesteer binne die tydelike werklikheid op Sinai in tien 'woorde' (debarim; Deut. $4: 13 ; 10: 4 ;$ vgl. $\$ 1.2$ en 2.1 ), gebooie van die tydelike lewe, wat hulle konvergerende integrasie vind in die bo-tydelike, ja ewige Torah, die ewige Logos. Daarom is die wet in hierdie pregnante, ewige gestalte, wat ver bo sy tydelike, Sinaittiese positiveringsgestalte uitgaan, die "Wet van Christus" (Gal. 6:2). Hy is die wet

welswoord in sy lydelike sin-breking onlsiaan 
se sin en vervulling (vgl. Matt. 5:17); Hy is sy telos (Rom. 10:4), dit wil sê sy sin en doel, en tegelyk die einde van die beperkte Sinaïtiese positiveringsgestalte van die wet wat in Hom sy hoër vervulling vind.

As Johannes 1 begin deur te sê dat die Logos "by" God was (pros: "teenoor", van aangesig tot aangesig, in intieme relasie, nou gemeenskap met God), dan verwys dit vermoedelik na Spreuke 8:30, waar die ewige Chokma (wysheid) 'n "kunstenaar" by God genoem word (1933-vertaling; volgens die vertaling van die Nederlandse Bijbelgenootschap: troetelkind). Die ewige Wysheid is elke dag God se vreugde, is by Hom en geniet en verlustig hom in die wêreld wat Hy gemaak het, in die wêreld van die mense. Hierdie Wysheid is God se skeppingswysheid, die Torah wat 'geld' vir die geskape werklikheid. Die skoonheid van die voorstelling is egter dat die wet hier nie slegs ' $n$ dor juridiese, deur God uitgevaardigde lex is nie, maar die verpersoonliking van sy ewige wysheid, van sy liefde vir en vreugde in sy skepping, ja, die Torah/Chokma self is die voorwerp van God se diepste geneentheid. Hierdie personifikasie is nie maar'n literêre hulpmiddel nie, maar verwys werklik na 'n persoon: Christus, die Seun van God. Die Wysheid van God is die ewige Torah, die Logos "by" (in gemeenskap met) God, die Seun in die boesem van die Vader (Joh.1:18), die "Engel" van Jahweh (malach, boodskapper, verteenwoordiger wat die wese van God tot uitdrukking bring). Christus is die vleesgeworde Logos (Joh. 1:14), ${ }^{10}$ die vleesgeworde Torah (vgl. Matt. 5:17; Ps. 40:9), die vleesgeworde Wysheid (1 Kor. 1:24,30; Kol. 2:2,3), die vleesgeworde Liefde. ( $\mathrm{Vgl}$. hiermee die feit dat die goddelike liefde die sin - die "som" en die "vervulling" - van die wet is; Matt. 22:34-40; Rom. 13:8-10; Gal. 5:13,14; Jak. 2:8.)

Die Wet is in die pregnante sin van die woord die bo-tydelike konvergensie en integrasie van alle tydelike wetskringe, van alle modale en entiteitswette wat die Skepper vir die tydelike lewe ingestel het. Die Liefde, eweneens in die pregnante, bo-tydelike sin van die woord (dus onderskeie van tydelike gestaltes daarvan soos huweliks-, ouer-, vaderlandsliefde, ens.), is die Wet se som, se diepste inhoud, en daarmee die sintotaliteit, die sentraal-religieuse worteleenheid van die hele temporele sinverskeidenheid (Dooyeweerd, 1984,II:144,149; III:71). Daarom kan gesê word dat God se wese (wysheid, krag, liefde, lig) in die Wet, die ewige Torah, uitgedruk lê. Daarom kan gesê word dat Christus, as Beeld van God (2 Kor. 4:4; Kol. 1:15), as afstraling van God se heerlikheid en ewebeeld van sy wese (Heb. 1:3), die ewige Torah is.

In die 'wet' gaan dit nie slegs om 'n belangrike wysgerige of teologiese begrip nie, maar

10 Dit is onbegryplik dal Dengerink (1986:120) sê dat dic Logos dic drie-enige God is: Vader, Seun en Heilige Gecs; die Logos is in dic Nuwe Testament altyd die Seun. 
in wese om 'n bo-teoretiese idee, wat verwys na die diepste dinge wat uiteindelik oor God en die wêreldorde gesê kan word, die hoogste dinge wat die geloof ken. Dit is vir die gelowige belangrik om homself daaraan te herinner, sodat sy Christelik-teoretiese denke altyd ingeraam bly in die baie breër kader van sy bo-teoretiese (ook bo-teologiese), sentraal-religieuse geloof, in die persoonlike gemeenskap met en onderworpenheid aan die ewige Torah of ewige Woord van God, die ware Wysheid van God, die Logos, Christus.

\section{BIBLIOGRAFIE}

BERKOUWER, (i.C. 1951. De algemene openbaring. Kampen : Kok DENGERINK, J.D. 1986. De zin van de werkelijkheid. Amsterdam : VU Uitgeverij

DOOYEWEERD, H. 1963. Vernicuwing en hezinning. Zutphen : Van den Brink \& Co

DOOYEWEERD, H. 1984 (repr.). A New Critique of Theoretical Thought. Jordan Station : Paideia Press.

GREIDANUS, S. 1901. The Universal Dimension of Law in the Hebrew Scripturcs. Tydskrif w Christelike Welenskap, 27:22-39.

GRUNDMANN, W. 1964, Dunamai/dunamis. (In Kittcl, G. \& G.W. Bromiley, cds. Theological Dictionary of the New Testament. Vol. II. Giand Rapids : Ecrdmans. p. 284-317.)

GUTBROD, W. 1967. Nomos. (In Kittcl, G. \& G.W. Bromiley, cas. Theological Dictionary of the Ncw Testament. Vol. IV. (Grand Rapids : Ecrdmans. p. 1(13,-1091.)

HART, H. 1984. Understanding Our World: An Integral Ontology, Lanham : University Press of Amcrica.

HEYNS, J.A. 1978. Dogmatick. Pretoria : NG; Kerkbockhandel.

KALSBEEK, L. 1970 . De wijsbegeerte der wetsidec. Amslerdam : Buijten \& Schipperheijn.

OUWENEEL, W.J. 1980. De leer van de mens. Amsıcrdam : Buijlen \& Schipperheijn

OUWENEEL. WJ. 1991. Die Godsopenharing in die naluur: 'n Teologiese en wysgerige studic. In dic' Skriflig, 25(3):383-400.

SCHMIDT, W.H. 1977. Dabar. (In Bollerweck, G.J. \& Ringgren, H. Hrsgb. Theologisches Worterbuch zum Alten Testament. Stuttgart ens. : Kohlhammer. kol. 101-133.)

SMIT, J.H. 1980]. Skcppingsopenbaring en welenskap. Tydskrif vir Christelike Wetenskap, 16:174-200.

STAFLEU, M.D. 1987. Theories al Work. Lanham : University Press of America.

STRAUSS, D.F.M. 1979. Dic tcorclicsc blootlegging van skcppingsbeginsels. Tydskrif vir Christclike Wetenskap, 15:254-264

STRAUSS, D.F.M. 1183. The Nature of Philosophy. Tydsknj vir Christelike Wetenskap, 19:40-55.

STRAUSS, D.F.M. 1988a. Bcgripsvorming in die sistemalicse tcologic. Tydskrif vir Christelike Wetcriskap, 24:124-161.

STRAUSS, D.F.M. 1988b. Ralionality and Universality: Conditions and Orderliness - on the Border of Concept and ldca. Koers, 53:613-641.

STRAUSS, D.F.M. 1900. Die mens en sy wêreld. Blocmfontein : Tekskor BK.

STRAUSS, D.F.M. \& VISAGIE, PJ. 1984. Dic verhouding tussen nic-teologiese wetenskappe en dic Icologic. Tydsknf vir Christelike Welenskap, 20(3/4 kw.):51-79.

TROOST, A. 1969. De openbaring Gods en de maalschappelijke orde. Philosophia Refonnata, 34:1-37.

VAN RIESSEN, H. 1980. Wijsbegecric. Kampen : Kok. 
Die wet van God - 'n teologiese en wysgerige studie

VOLLENHOVEN, D.H.Th. 1933. Het Calvinisme en de reformatic van de wijsbegecrte. Amsterdam : Paris.

VOLLENHOVEN, D.H.Th. 1963. College systematick: Het problecm van de tijd. Afgerolde aantekenings van J.C. Vander Stelt. 